DOI https://doi.org/10.18551/rjoas.2017-10.16

\title{
EMPLOYEE PROMOTION PLANNING IN ANALYTICAL HIERARCHY PROCESS PERSPECTIVE: STUDY ON NATIONAL PUBLIC PROCUREMENT AGENCY
}

\author{
Ayuningtyas Adreng Kusuma*, Saleh Choirul, Noor Irwan \\ Faculty of Administrative Science, University of Brawijaya, Indonesia \\ *Email: adrengkusuma@gmail.com
}

\begin{abstract}
The promotion process is part of the career development conducted by Civil State Apparatus Employee (Pegawai Aparatur Sipil Negara) which should be implemented by applying merit system. Employee-related strategic decision making has not applied merit system as mandated in applied laws. It occurred due to Public Service Appointment Board (Badan Pertimbangan Jabatan dan Kepangkatan) not possessing assessment model and criteria which could be used to support promotion process implementation in the appropriate structural position based on employee competence and performance. This study aims to describe and analyze assessment criteria and subcriteria required to be considered in State Civil Servant Officers promotion planning by applying Analytical Hierarchy Process (AHP) method in National Public Procurement Agency (Lembaga Kebijakan Pengadaan Barang/Jasa Pemerintah). This study uses the explanative quantitative univariate method. Data collection technique used questionnaire instrument. Analytical tool used was AHP. Research result exhibits that ASN employee promotion planning using assessment model is described as follows: (1) Employee Performance Assessment consist of Employee Work Performance element with three criteria and Employee Work Behavior with twenty-three criteria; and (2) Evaluation of Employee Promotion Implementation with eleven criteria. Through the use of AHP methods employee, promotion planning could be utilized as a tool for Baperjakat to produce employee decisions that will be promoted objectively and effectively.
\end{abstract}

\section{KEY WORDS}

Employee promotion, assessment, model, criteria, Analytical Hierarchy Process.

In carrying out government duties and national development, it required the support and professionalism of the State Civil Service Officer (ASN) owned by each Government Agency. One of the efforts made by the Government nurturing professional, qualified and competent ASN employees is through career development. Employee promotion is part of the employee development function and as a follow-up of the employee performance assessment results.

In order to achieve the accuracy of the employee promotion process in structural positions, it is necessary to have a merit system with the principle that a person's placement, promotion, and retirement is done on the basis of objective standards and tests of Performance and ability (Tjokroamidjojo, 1995, in Prasodjo and Rudita, 2014: 15). According Sunaryo (2014: 2) Merit system is the most appropriate mechanism in the development of human resources bureaucracy because it provides an illustration of bureaucratic management proportionally and professionally. Highly competent and contributing employees will have greater opportunity to gain career development than less competent employees.

Implementation of personnel management starting from planning, recruitment, career development, rewards and dismissals or retirement to date is still not fully based on competence and performance considerations. The elements of seniority and subjectivity still dominate in every placement. Employee placements are still determined political officials preference or like/dislike (Prasodjo and Rudita, 2014: 13). The main problem with performance Assessment is that assessors are highly subjective and it is difficult to achieve consistency between ratings given by different assessors because the notion of performance 
is often unclear, which in turn, increases subjectivity (Armstrong and Taylor 2014: 340). Therefore, it takes a wise thinking and decision making in the process of employee promotion and performance Assessment as the basis of appreciation and professionalism in managing good governance as mandated in Law Number 5 Year 2014 on State Civil Apparatus.

National Public Procurement Agency (LKPP) is a non-ministerial government institution established by the President in 2008 through Presidential Regulation No. 106/2007. Under the Presidential Regulation, LKPP is the only Government Agency that has the task of developing and formulating Government procurement. Personnel strategic decision making in LKPP is determined by the Public Service Appointment Board (Baperjakat). Various considerations or policies are required to ensure that an appropriate and strategic posture for a selected person to occupy the position.

So far, strategic decision-making process related to promotion in structural positions in LKPP has no assessment model and criteria that can be used to support promotion process implementation in structural positions according to employee competence and performance. The assessment model used by Baperjakat consideration in making promotion decisions on structural positions only based on one or two assessment criteria without considering other assessment criteria. This raises the high degree of decision-making subjectivity, whereby human decision makers will be constrained on like and dislike factors (spoil system).

Based on the described phenomenon, it is necessary to form an assessment method that can take into account the various criteria or considerations in each assessment. It is conducted to reduce the subjectivity of the decision-making process in employee promotion. Employees who possess the competence and other considerations could be selected in the promotion process. Therefore, Baperjakat as a strategic decision maker in personnel field requires knowledge and information that supports decision making and capable to produce an alternative decision, either through decision support system or compound criteria analysis by AHP method. In this regard, this study aims to describe and analyze criteria and subcriteria of assessment that need to be considered in the employee promotion planning through the implementation of the AHP method in LKPP.

\section{LITERATURE REVIEW}

Human Resource Planning. Human resources are one of the main assets of the organization that plays an important role in organization development. Human resources must be managed properly. In human resource planning, the focus of attention is the specific steps taken by management to ensure that the organization is available to the appropriate employees to occupy the various positions, positions and work in achieving the goals and objectives of the organization (Siagian 2015: 41 ).

Employee Promotion. Promotion is the process of movement from one Work to another within a higher hierarchy of authority and responsibility to the authority and responsibility that have been given to the workforce in the past (Noe et.al., 2007: 299). According to Siagian (2005: 169), promotion is an employee transferred from one Work to another whose responsibilities are greater, higher level office hierarchy and greater income. According to Siagian (2005: 170), organizations generally use two main bases in considering employees to be promoted namely work performance and seniority. According to Law Number 5 Year 2014 Article 72 paragraph 1 explains that the promotion of civil servants is done based on objective comparison between competence, qualifications, and requirements needed in the position, performance assessment, leadership, cooperation, creativity and consideration from Performance Assessment Team of Government Civil Servant (PNS), regardless of gender, ethnicity, religion, race, and class. In the implementation of civil servant promotion, to occupy a structural position there are criteria or conditions based on Government Regulation No. 13 of 2002 on the Appointment of Civil Servants in Structural Positions, to be appointed in a structural position then a civil servant must meet several requirements, which are described as follows: 
1. Registered as Civil Servant, possessing rank at least 1 (one) level below the determined rank level;

2. Possess the qualifications and education level specified;

3. All elements of the performance Assessment are at least of good value in the last two years;

4. Possess the competence required in appointed office, physically and mentally healthy;

5. In addition to these requirements, Civil Servants should consider the following factors: seniority in rank, age, education and training; and experience.

According to Siagian (2009: 176), the terms of promotion include experience, level of education, loyalty, honesty, responsibility, work performance and initiative, and creativity. According to Manullang (2001: 101), there are some common requirements of qualifying for selection, including expertise, experience, age, gender, education and training, physical/health conditions, talents, and character.

Analytical Hierarchy Process. AHP is one of the decision-making methods developed by Saaty. The basis of AHP method is to acknowledge problems, the purpose of making decisions, determining criteria, sub-criteria and alternatives to determine the best priority related to the criteria and subcriteria in decision making (Saaty, 2008: 84). According to Kusrini (2007), some principles in solving problems using AHP include:

1. Create a hierarchy. Complex systems can be understood by breaking them into supporting elements, arranging elements hierarchically and combining them.

2. Assessment criteria and alternatives. Criteria and alternatives are done by comparing pairs. According to Saaty, for a variety of issues, a scale of 1 to 9 is the best scale for expressing opinions and making pairwise comparisons of some elements. This scale can facilitate the relative calculation between objects with a high degree of accuracy and required in AHP. The value and definition of qualitative opinion from Saaty comparison scale can be measured using the analytical table as exhibited in Table 1.

Table 1 - Pairing Comparison Assessment Scale

\begin{tabular}{ll}
\hline Importance Rank & Description/ Definition \\
\hline 1 & Criterion / Alternative A is as important as Criteria / Alternative B \\
3 & Criterion / Alternative A is slightly more important than Criteria / Alternative B \\
5 & Criterion / Alternative A is more important than Criteria / Alternative B \\
7 & Criterion / Alternative A is significantly more important than Criteria / Alternative B \\
9 & Criterion / Alternative A is absolutely more important from Criteria / Alternative B \\
$2,4,6,8$ & When in doubt between two adjacent values \\
\hline
\end{tabular}

Source: Saaty (2008:86).

3. Set priorities. For each criterion and alternative, a pairwise comparison is required. The relative comparison values of all the alternative criteria can be adjusted to the predetermined judgment to generate weight and priority. Weights and priorities are calculated by manipulating matrices or solving mathematical equations.

4. Logical Consistency. Consistency has two meanings. First similar objects can be grouped according to uniformity and relevance. Second, it concerns the level of relationship between objects based on certain criteria.

\section{METHODS OF RESEARCH}

The research method used is quantitative research which aims to describe and analyze the criteria of Assessment of employee promotion by using careful measurement technique that is AHP method so that will yield the conclusion. This research is a survey research by using questionnaires as the main data collection tool, interviews, and literature study. The research was conducted in LKPP Office, Jakarta. The sampling technique uses a non-probability sample technique with the selected sample or purposive sample. This study used two questionnaires with two different types of samples, 
determination of assessment criteria questionnaire on 10 samples. Weighted criteria assessment questionnaire with a total sample of 30 people. Analysis of research data was conducted using AHP and the resulting data will be analyzed in univariate manner, which is an analysis of independent variables without comparing with other variables. As a result, description and explanation of criteria and subcriteria assessment used in planning promotion of employees were obtained.

\section{RESULTS AND DISCUSSION}

Description of Respondent's Characteristics. The respondent characteristic of the assessment criteria determination is described as follows: $40.0 \%$ of respondents aged over 50 years, $50.0 \%$ of respondents occupy the position as Senior High Official and is the chairman and member of Baperjakat, $50.0 \%$ of respondents have rank/group of Major Supervisor (IV/d), 40.0\% respondents have recent Bachelor's education level and most $60.0 \%$ work in the Main Secretariat work unit. The characteristics of respondents in weighing the assessment criteria were $43.3 \%$ aged between $31-35$ years, $73.3 \%$ of respondents occupied the position as Supervisory Officials with $53.0 \%$ having rank/class of Penata (III / c), $56.7 \%$ of respondents had Masters level and $43.3 \%$ working on the Main Secretariat work unit.

Data Analysis of Assessment Criteria Determination. In any decision-making will be preceded by identifying the problem to be solved. The use of the AHP method begins with the identification of the problem and then describes it to be the main elements to support the chosen decision. These elements could be utilized as alternatives or subcriteria in determining the alternatives priority. The process of hierarchy compilation involves the assessment of some experts in the field of human resource management as well as LKPP personnel decision-makers so that problems can be described in the hierarchy appropriately.

The result of the assessment criteria exhibits experts' agreement on employee performance Assessment consists of 2 (two) elements: Employee Work Performance with an average weight of $55 \%$ and Employee Work Behavior with an average weight of $45 \%$. Elements of Employee Performance consists of 3 (three) criteria, namely work quality, quantity and time. This is in line with the statements of Bernardin and Russell (1993: 107) and Simamora (2004: 612) that the main criteria used in performance Assessments include work quality, quantity, and time. Elements of Employee Behavior consists of 5 (five) criteria derived from Core Values LKPP which are Integrity, Professionality, Compliance, Orientation to stakeholders and Team Work. These five criteria have sub-criteria with a total of 23 (twenty-three) criteria. The use of Core Values of LKPP as a criterion in the element of employee's work behavior because in addition to the performance achieved, the employee should uphold the core value in each behavior in carrying out its work. This is in accordance with Armstrong's opinion (2009: 68) which emphasizes that assessing how well individuals retain the core values of an organization is an integral part of performance management.

Furthermore, the experts evaluated the proposed criteria for employee promotion implementation from several sources, namely Law Number 5 Year 2014, Government Regulation Number 11 Year 2017, Government Regulation No. 13/2002, Siagian (2009) and Manullang (2001). Based on the results of the assessment, employee promotion implementation assessment consists of 11 (eleven) criteria: rank/class, age, formal education, leadership training, technical and functional training, employee performance Assessment, competency assessment, Work experience, physical and spiritual, and disciplinary punishment. After the criteria and subcriteria assessments are considered feasible, a hierarchy of employee performance assessment and employee promotion assessment was formed to be used in LKPP as presented in Figure 1 and Figure 2 below.

Weighted Assessment Criteria and Subcriteria Data Analysis. After determining the criteria and subcriteria in hierarchy form, the weighing was conducted by 30 (thirty) respondents consisting of Administrator and Supervisory Officers to determine the 
importance of each assessment criterion and subcriteria by using the Saaty scale to produce a pairwise comparison matrix. The result of weighting criteria and subcriteria of employee performance Assessment and employee promotion implementation Assessment is presented in Table 2.

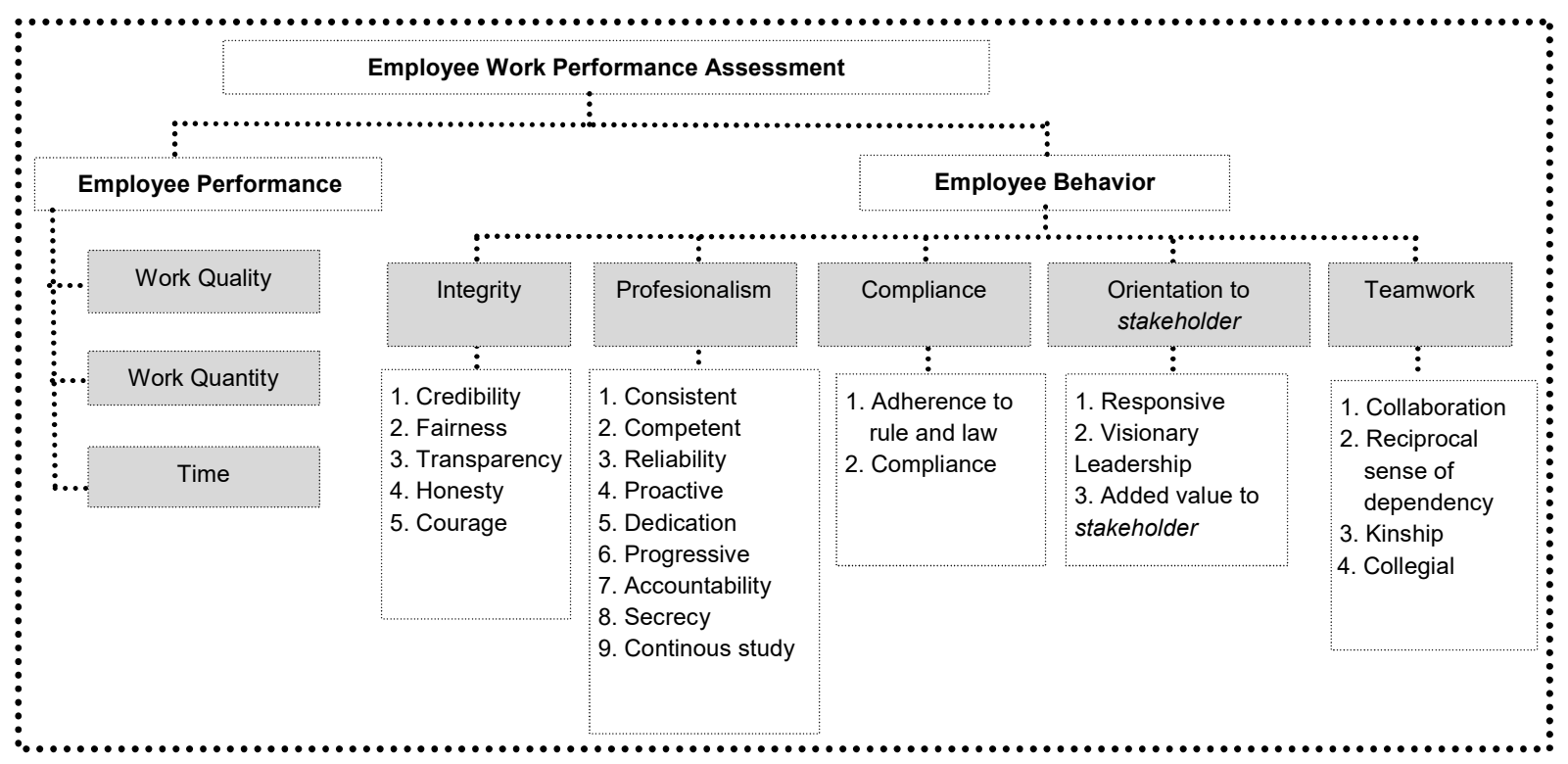

Figure 1 - Employee Work Performance Assessment

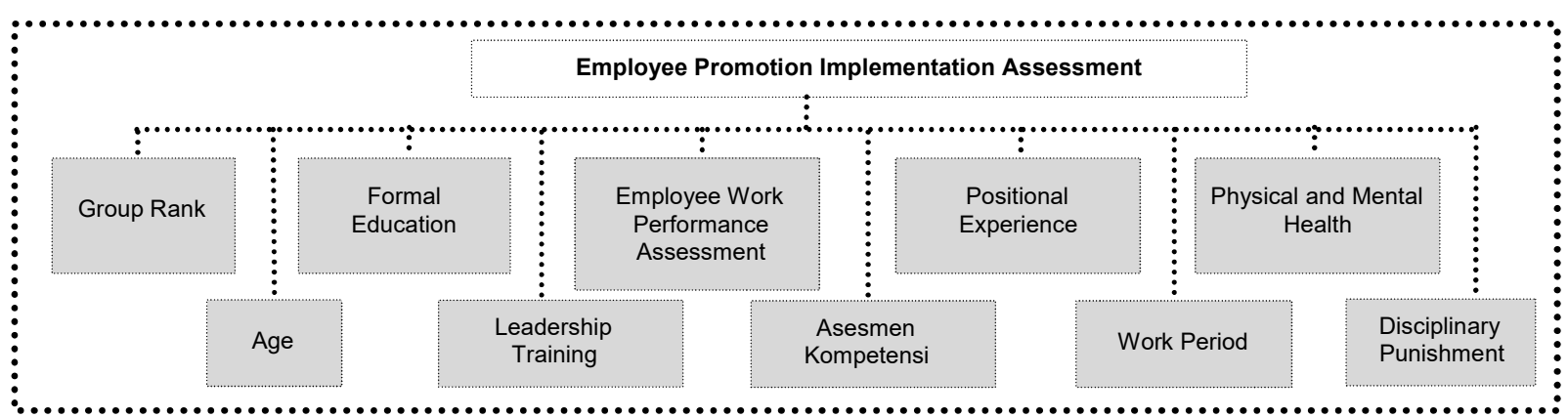

Figure 2 - Employee Promotion Implementation Assessment

Employee performance Assessment exhibits three criteria on Employee Performance element indicate that work quality weighed to 0.6426 or $64.26 \%$. Work Quality is an activity undertaken by employees who have met the various requirements, specifications, and expectations that have been established (Hasibuan, 2007: 45). Employee work quality is seen when employees prioritize quality of work processes and results. Employee Behavior exhibits honesty subcriteria obtained the highest weight, out of 23 subcriteria, at 0.1551 . Honesty is the forerunner of a civil servant to be able to build high integrity. Being honest during work is done through working with others honestly and truthfully and presenting complete and accurate information and complying with applicable regulations.

In the assessment of employee promotion implementation, competency assessment criteria obtained the highest weight at 0.1937. Government Regulation No. 13 Year 2002 stated that the requirement to be appointed in a structural position is to have the required Work competence. One method used was competency examination known as an assessment center. It is a standardized assessment method to measure the competence and successful prediction of civil servants in the position to be occupied. The Assessment Center results will determine the classification of candidates for structural officials whether candidates meet the minimum requirement or not to fulfill the Work requirements. This is in accordance with the opinion of Fillipo (1994) which states that the central objective of an 
Assessment Center is selection and promotion decisions by identifying the strengths and weaknesses of candidates for development purposes.

Table 2 - Criteria and Sub Criteria Weighing Analysis on Assessment of Employees Work Performance and Implementation of Employee Promotion

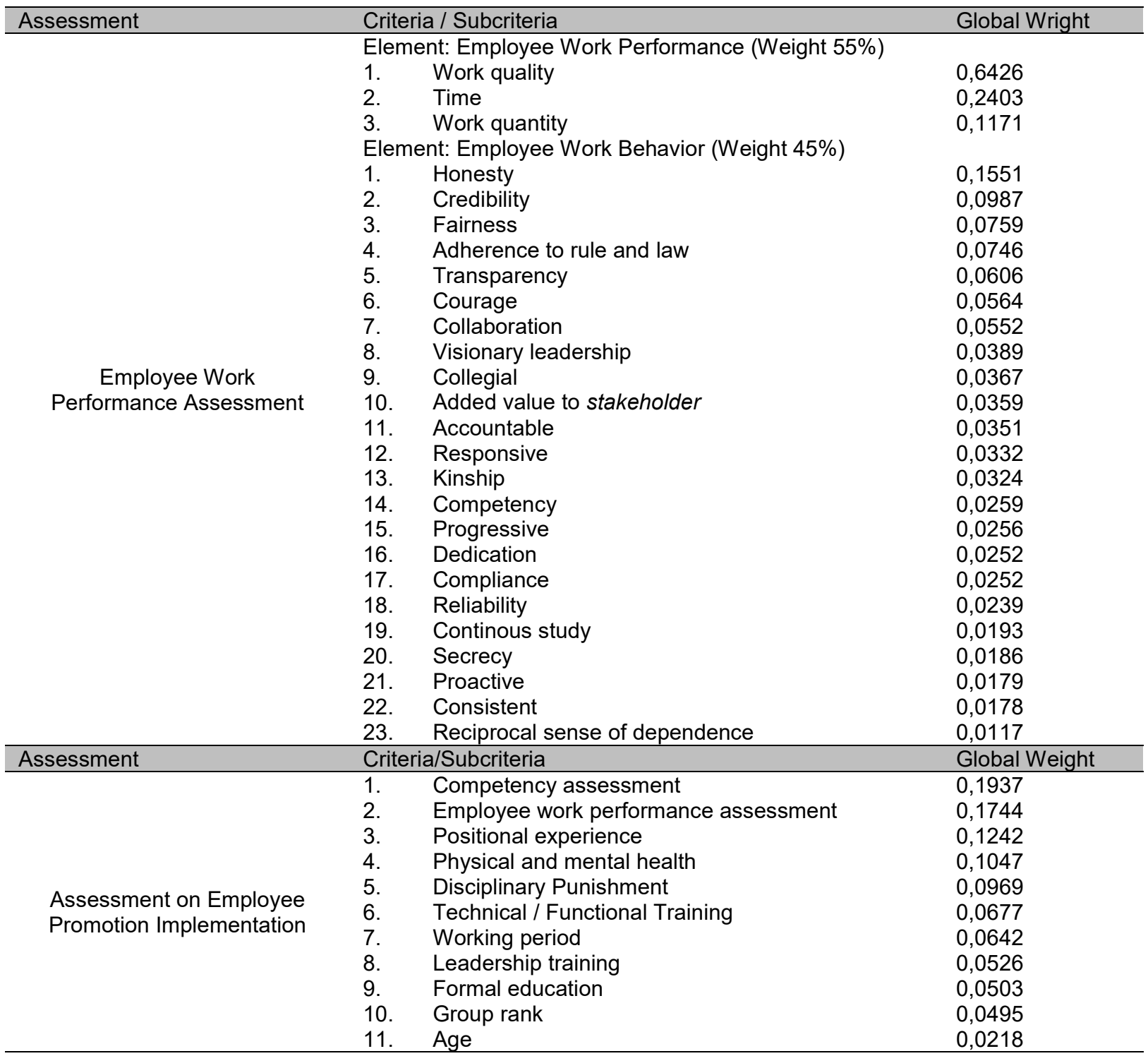

\section{Validity and Reliability Analysis}

Hierarchy process is the most important step in preparing the AHP model. The lack of clarity or error in answering a question can make the decision makers choose poorly a criterion or subcriteria, therefore, questions should be answered consistently. Validity and reliability are required in order for a model to be tested (Permadi, 1992). According to Permadi (1992: 14), one of the main assumptions of the AHP method that distinguishes it from other decision-making models is the absence of absolute consistency condition. AHP method used in this study involves human perception as its input, the inconsistency may occur because human beings have limitations in expressing their perceptions consistently especially if they have to compare many criteria/subcriteria assessment. Validity and reliability test in this research is done by utilizing AHP method using Consistency Ratio (CR) calculation. The consistency measurement result on assessment criteria and subcriteria are presented in Table 3. 
Table 3 - Criteria and Sub Criteria Consistency Measurement Result on Employee Performance Assessment and Employee Promotion Implementation Assesment

\begin{tabular}{lllll}
\hline Criteria/Subcriteria & Matrix Size & $\lambda$ max & $\begin{array}{l}\text { Consistency } \\
\text { Index (CI) }\end{array}$ & $\begin{array}{l}\text { Consistency } \\
\text { Ratio (CR) }\end{array}$ \\
\hline Criteria: & & & & \\
\hline 1. Employee performance & 3 & 3,0080 & 0,0040 & 0,0069 \\
2. Employee behavior & 5 & 5,0787 & 0,0197 & 0,0176 \\
3. Employee promotion implementation assessment & 11 & 11,4321 & 0,0432 & 0,0286 \\
\hline Employee behavior subcriteria: & & & & \\
\hline 1. Integrity & 5 & 5,0225 & 0,0056 & 0,0050 \\
2. Profesionalism & 9 & 9,1232 & 0,0154 & 0,0106 \\
3. Compliance & 2 & 2,0000 & 0,0000 & 0,0000 \\
4. Orientation to Stakeholder & 3 & 3,0106 & 0,0053 & 0,0092 \\
5. Teamwork & 4 & 4,0368 & 0,0123 & 0,0136 \\
\hline
\end{tabular}

According to Permadi (1992: 17), the limitation of whether or not the consistency of a matrix is actually non-existent. But based on some experiments and experience, the inconsistency level of $10 \%$ and below is an acceptable level of inconsistency. Based on the value of Consistency Ratio (CR) in Table 3, it exhibits that all criteria and subcriteria assessment in this study has a CR value smaller than 0.1 . This explains that the pairwise comparison matrix between the criteria or subcriteria in this study is consistent and the criteria/subcriteria can be used as a tool of Baperjakat in the implementation of the employee promotion process in LKPP.

Illustration of Work Performance Assessment and Implementation of Employee Promotion. The criteria/subcriteria global weight of the previously achieved work Performance is multiplied by assessment score (Likert scale 1 through 5) to obtain the Work Performance Value (NPK) on both the Employee Performance Performance and Employee Work Behavior. The calculation format Employee Performance Value (NPKP) is as follows:

$$
N P K P=[(C K P \text { Weight }) \% \times N P K(C K P)]+[(P K P \text { Weight }) \% \times N P K(P K P)]
$$

Assessment criteria on Employee Performance using score criteria in accordance with Head of State Personnel Agency Regulation No. 1 of 2013. On the other hand, subcriteria score on the assessment of Employee Behavior used Behavioral Observation Scale (BOS) based on observation on the frequency of work behavior using Likert scale 5 points i.e never, rarely, occasionally, generally and often (Noe et.al., 2011: 229). After obtaining Employee Performance Value, the value is interpreted into the assessment interval described as follows:

Table 4 - Criteria Interpretation of Employee Performance Values

\begin{tabular}{cc}
\hline Employee Performance Interval Values & Interpretation \\
\hline $4,0001-5,0000$ & Very Good \\
$3,0001-4,0000$ & Good \\
$2,0001-3,0000$ & Adequate \\
$1,0001-2,0000$ & Poor \\
$0,0000-1,0000$ & Very Poor \\
\hline
\end{tabular}

The illustration of performance Assessment of an employee "A" is presented in Table 5 below.

Table 5 exhibits that Employee Performance Value "A" is 3.7930 and is included in the "Good" rating interval. Similar to the illustration of employee performance Assessment, in preparing illustration of employee promotion implementation assessment, the promotion implementation assessment criteria score is required. These criteria are described in the following Table 6.

The illustration of the Official Candidates promotion implementation assessment is presented in the following Table 7. 
Table 5 - Illustration of Employee Performance Assessment

\begin{tabular}{|c|c|c|c|c|}
\hline \multicolumn{2}{|c|}{ Criteria / Subcriteria } & Global Weight & Score & Value \\
\hline \multicolumn{5}{|c|}{ Elements: Employee Performance, Weight: $55 \%$} \\
\hline 1. & Quality & 0,6426 & 4 & 2,5704 \\
\hline 2. & Time & 0,2403 & 4 & 0,9612 \\
\hline 3. & Quantity & 0,1171 & 3 & 0,3513 \\
\hline \multicolumn{4}{|c|}{ Total } & 3,8829 \\
\hline \multicolumn{4}{|c|}{ Work Performance Grade (Total x Weight $55 \%$ ) } & 2,1356 \\
\hline \multicolumn{5}{|c|}{ Elements: Employee Work Behavior, Weight: $45 \%$} \\
\hline 1. & Honesty & 0,1551 & 5 & 0,7755 \\
\hline 2. & Credibility & 0,0987 & 4 & 0,3948 \\
\hline 3. & Fairness & 0,0759 & 4 & 0,3036 \\
\hline 4. & Adherence to rule and law & 0,0746 & 4 & 0,2984 \\
\hline 5. & Transparency & 0,0606 & 4 & 0,2424 \\
\hline 6. & Courage & 0,0564 & 3 & 0,1692 \\
\hline 7. & Collaboration & 0,0552 & 4 & 0,2208 \\
\hline 8. & Visionary leadership & 0,0389 & 2 & 0,0778 \\
\hline 9. & Collegial & 0,0367 & 4 & 0,1468 \\
\hline 10. & Added value to stakeholder & 0,0359 & 3 & 0,1077 \\
\hline 11. & Accountable & 0,0351 & 3 & 0,1053 \\
\hline 12. & Responsive & 0,0332 & 3 & 0,0996 \\
\hline 13. & Kinship & 0,0324 & 3 & 0,0972 \\
\hline 14. & Competency & 0,0259 & 3 & 0,0777 \\
\hline 15. & Progressive & 0,0256 & 2 & 0,0512 \\
\hline 16. & Dedication & 0,0252 & 2 & 0,0504 \\
\hline 17. & Compliance & 0,0252 & 4 & 0,1008 \\
\hline 18. & Reliability & 0,0239 & 3 & 0,0717 \\
\hline 19. & Continous study & 0,0193 & 3 & 0,0579 \\
\hline 20. & Secrecy & 0,0186 & 4 & 0,0744 \\
\hline 21. & Proactive & 0,0179 & 3 & 0,0537 \\
\hline 22. & Consistent & 0,0178 & 4 & 0,0712 \\
\hline 23. & Reciprocal sense of dependence & 0,0117 & 3 & 0,0351 \\
\hline \multicolumn{4}{|c|}{ Jumlah } & 3,6832 \\
\hline \multicolumn{4}{|c|}{ Work Performance Grade (Total x Weight $45 \%$ ) } & 1,6574 \\
\hline \multicolumn{4}{|c|}{ Employee Work Performance Grade (NPKP) } & 3,7930 \\
\hline
\end{tabular}

Table 6 - Implementation of Employee Promotion Assessment Grade

\begin{tabular}{lll}
\hline Criteria & Grade & Indicator \\
& 1 & Performance value: 50 below \\
Employee Performance Assessment & 2 & Performance value: 51 - 60 \\
& 3 & Performance value: $61-75$ \\
& 4 & Performance value: 76 - 90 \\
& 5 & Performance value: 91 above \\
\hline & 1 & Low / Less in accordance with the intended position \\
Competency Assessment & 2 & Medium Low / Not in accordance with the intended position \\
& 3 & Medium High / Sufficient according to the intended position \\
& 4 & High / In accordance with the intended position \\
& 5 & Very High / Very appropriate with the intended position \\
\hline
\end{tabular}

*) Partially shown data.

Tabel 7 - Implementation of Employee Promotion Asssessment Illustration

\begin{tabular}{lllll}
\hline No & Scoring Criteria & Global Weight & Score & Total \\
\hline 1. & Competency assessment & 0,1937 & 5 & 0,9685 \\
2. & Employee work performance assessment & 0,1744 & 4 & 0,6976 \\
3. & Positional experience & 0,1242 & 3 & 0,3726 \\
4. & Physical and mental health & 0,1047 & 3 & 0,3141 \\
5. & Disciplinary Punishment & 0,0969 & 4 & 0,3876 \\
6. & Technical / Functional Training & 0,0677 & 2 & 0,1354 \\
$7 . \quad$ Working period & 0,0642 & 2 & 0,1284 \\
8. & Leadership training & 0,0526 & 1 & 0,0526 \\
9. & Formal education & 0,0503 & 3 & 0,1509 \\
$10 . \quad$ Group rank & 0,0495 & 1 & 0,0495 \\
$11 . \quad$ Age & 0,0218 & 4 & 0,0872 \\
\hline Total Score & & & 3,3444 \\
\hline
\end{tabular}


Based on the illustration presented in Table 6 and Table 7, an assessment could be made of several prospective employees who will occupy the structural position. By comparing each employee's Performance final value resulting in prioritized employee eligible for promotion in structural positions. Through the assessment utilizing AHP in this study, Baperjakat could be more objective in making employee promotion decisions.

\section{CONCLUSION}

This study aims to describe and analyze assessment criteria required to be considered in the employee promotion planning by applying AHP method to LKPP. Based on the research result, it can be concluded that an employee promotion planning using assessment model consisted of: (1) Employee performance Assessment consisting of 2 elements. Employee Work Performance weighing 55\% with 3 criteria. Employee Work Behavior weighing $45 \%$ with 23 subcriteria. Weighing criteria and subcriteria producing the highest global weight is work quality on CKP elements at 0.646. Subcriteria honesty at 0.1551 ; and (2) assessment of employee promotion which consists of 11 criteria. The highest global weight is competence assessment criterion at 0.1937 . AHP usage in this study can generate priority weighting on criteria and subcriteria to be used and applied as a tool of assessment for Baperjakat in planning employee promotion, especially in structural positions. Therefore decision maker subjectivity factor can be reduced.

This study still has limitations that can be developed in further research. First, the implementation of the merit system as mandated by the prevailing laws and regulations needs to be reviewed and improved by LKPP. Through the improvement of employee promotion system, the assessment model with AHP method can be used and applied as a tool of Baperjakat in the decision making of LKPP employee promotion planning. Secondly, the results of this research need to be developed through a decision support system integrated with LKPP Personnel Information System to facilitate the Personnel Section and Baperjakat in assessing and acknowledging the rank of employees entitled to occupy structural positions in LKPP. Third, this study uses LKPP Core Values as a criterion of assessment on Employee Work Behavior elements. In future practices, this method could use/add other criteria as needed.

\section{REFERENCES}

1. Armstrong, Michael. 2009. Armstrong's Handbook of Performance Management (4th Edition). London and Philadelphia: Kogan Page.

2. Armstrong, Michael and Taylor, Stephen. 2014. Armstrong's Handbook of Human Resource Management Practice (13th Edition). London and Philadelphia: Kogan Page.

3. Bernardin, John H., dan Russel, Joyce, ES. 1993. Human Resources Management. New York: Mc. Graw-Hill.

4. Hasibuan, Melayu. 2007. Manajemen Sumber Daya Manusia (Dasar dan Kunci Keberhasilan). Jakarta: PT Toko Gunung Agung.

5. Kusrini. 2007. Konsep dan Aplikasi Sistem Pendukung Keputusan. Yogyakarta: Andi.

6. Manullang. 2001. Manajemen Sumber Daya Manusia. Yogyakarta: BPFE

7. Noe, Raymond A., Hollenbeck, John R., Gerhart, Barry, Wright, Patrick M. 2007. Fundamentals of Human Resource Management. 2nd Edition. New York: McGraw-Hill.

8. Noe, Raymond A., Hollenbeck, John R., Gerhart, Barry, Wright, Patrick M. 2011. Fundamentals of Human Resource Management (4th Edition). New York: McGrawHill/Irwin.

9. Prasodjo, Eko. dan Rudita, Laode. 2014. "Undang-Undang Aparatur Sipil Negara: Membangun Profesionalisme Aparatur Sipil Negara". Dalam Jurnal Kebijakan dan Manajemen PNS, Volume 8 Nomor 1.

10. Peraturan Pemerintah Nomor 11 Tahun 2017 tentang Manajemen Pegawai Negeri Sipil.

11. Permadi, Bambang. 1992. AHP. Jakarta: Pusat Studi Antar Universitas-Studi Ekonomi Universitas Indonesia. 
12. Saaty, TL. 2008. "Decision Making with The Analytical Hierarchy Process". In International Journal Services Sciences, Volume 1.

13. Siagian, Sondang P. 2005. Fungsi-Fungsi Manajemen. Jakarta: Bumi Aksara.

14. Siagian, Sondang P. 2009. Kiat Meningkatkan Produktivitas Kerja. Jakarta: PT Rineka Cipta.

15. Siagian, Sondang P. 2015. Manajemen Sumber Daya Manusia. Jakarta: Bumi Aksara.

16. Simamora, Henri. 2004. Manajemen Sumber Daya Manusia. Edisi Ketiga Cetakan Pertama. Yogyakarta: STIE YKPN.

17. Sunaryo, Bambang dan Cicellia, Celly. 2014. "Nilai Penting Affirmative Action Policy Dalam Pengembangan Sumber Daya Manusia (SDM) Aparatur Berbasis Merit". Jurnal Kebijakan dan Manajemen PNS, Volume 8 Nomor 1. 